\title{
ОЦІНКА СТАНУ ЗДОРОВ'Я ТА РІВНЯ ФІЗИЧНОГО РОЗВИТКУ СТУДЕНТІВ ЛУЦЬКОГО БАЗОВОГО МЕДИЧНОГО КОЛЕДЖУ
}

\author{
А. В. Романюк ${ }^{1}$ Н. І. Рега ${ }^{2}$, I. Я. Господарський ${ }^{2}$ \\ ${ }^{1}$ Луцький базовий медичний коледж \\ ${ }^{2}$ Тернопільський національний медичний університет \\ імені І. Я. Горбачевського мОЗ Украӥни
}

У статті наведено дані про стан здоров’я та рівень фізичного розвитку студентів Луцького базового медичного коледжу на основі оцінки проби Руф’є та наявності хронічних захворювань 3 метою надання ефективних рекомендацій щодо зміцнення здоров’я студентів.

\section{EVALUATION OF HEALTH AND LEVEL OF PHYSICAL DEVELOPMENT OF STUDENTS OF LUTSK BASIC MEDICAL COLLEGE}

\author{
A. V. Romanyuk ${ }^{1}$, N. I. Reha ${ }^{2}$, I. Ya. Hospodarskyi ${ }^{2}$ \\ ${ }^{1}$ Lutsk Basic Medical College \\ ${ }^{2}$ I. Horbachevsky Ternopil National Medical University
}

The article adduces the health condition and level of physical development of students of Lutsk Basic Medical College in the article based on the evaluation of the Ruffier test and the presence of chronic diseases.

Вступ. Науково-технічний прогрес став мимовільною причиною загострення загальнолюдської проблеми гіподинамії та погіршення рівня здоров'я людей. Суспільство страждає від багатьох різноманітних хвороб, причому кількість хворих, на жаль, не зменшується, а навпаки зростає. Особливу групу серед молоді становлять студенти. В останні роки активізувалася увага до здорового способу життя студентів. Це пов'язано із заклопотаністю суспільства з приводу здоров'я фахівців, яких випускає вища школа, зростання захворюваності в процесі професійної підготовки, наступним зниженням працездатності [1]. Проблему охорони здоров'я студентів вивчено недостатньо. Цьому потенційно найціннішому трудовому ресурсу суспільства на сьогодні не приділяють належної соціальної уваги, особливо за умов економічної кризи. Студентська молодь як майбутнє країни має розраховувати на цілеспрямовану державну турботу, підвищення рівня здоров'я та якості медичної допомоги. Нині назріла необхідність у розробці сучасної системи контролю за фізичним станом студентської молоді, яка 6 відповідала вимогам сучасності. Вивчення стану

(ङ) А. В. Романюк, Н. І. Рега, І. Я. Господарський, 2019 здоров'я студентської молоді як частини суспільства має важливе значення для створення системи для управління цим процесом [2].

Сьогодні спостерігають збільшення кількості студентів спеціальних медичних груп вищих навчальних закладів [3]. Така тенденція відбувається на фоні низького рівня фізичної підготовленості студентів, послаблення функцій нервової системи впродовж навчання та в період сесії, що негативно впливає на формування здоров'я майбутніх фахівців $[4,5]$.

Виникнення вже в молодому віці серцево-судинних захворювань, розладів роботи органів травлення, порушень мозкового кровообігу, онкологічних уражень, ендокринної патології та інших хвороб диктує необхідність вивчення особливостей і причин розвитку захворюваності та формування профілактичних заходів із широким їх застосуванням ще в преморбідному періоді [6, 7].

Метою дослідження було визначення результатів проби Руф'є та наявності хронічних захворювань у студентів Луцького базового медичного коледжу з метою надання ефективних рекомендацій щодо зміцнення здоров'я студентів та наукового обґрунтування

4 ISSN 2411-1597. МЕДСЕСТРИНСТВО. 2019. № 4 
розробки профілактичних програм для збереження стану здоров'я майбутніх медичних працівників.

Основна частина. Дослідження проведено на базі Луцького базового медичного коледжу протягом 2018 p.

У ході дослідження проаналізовано основні медичні документи (амбулаторні картки, медичні довідки та дані обстеження студентів) та оцінено результати проби Руф'є.

Проведено оцінку індексу Руф'є у 100 студентів Луцького базового медичного коледжу в 2018 р.

Результат після проведення тесту оцінено як:

- відмінний;

- добрий;

- задовільний;

- слабкий;

- незадовільний.

Отримані результати наведено на рисунку 1.

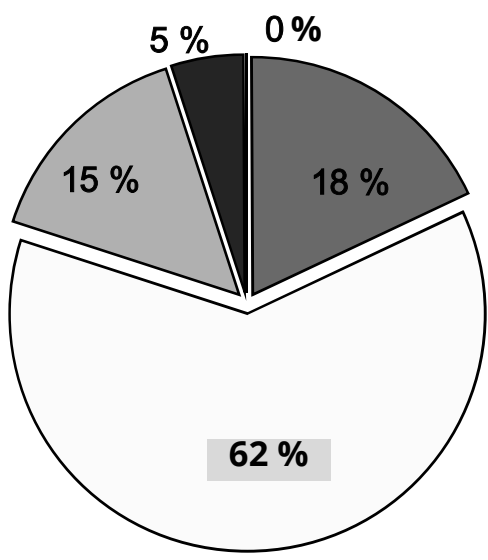

\section{$\square$ Відмінний \\ 口 Добрий \\ $\square$ Задовільний \\ $\square$ Слабкий \\ $\square$ Незадовільний}

Рис. 1. Структура результатів оцінки проби Руф'є.

За даними рисунка 1, переважно мав місце задовільний результат проби Руф'є (62 \%). Дуже насторожуючим $\epsilon$ те, що відмінних результатів не було взагалі, а незадовільних, які свідчать про критичну детренованість серцево-судинної системи, було, відповідно, $15 \%$. Практично у 6-7 студентів був критичний стан серцево-судинної системи, що $є$, без сумніву, вкрай тривожним сигналом та вимагає негайних дій щодо покращення рівня фізичного стану студентів.

Також нами обстежено 100 студентів Луцького базового медичного коледжу в 2018 р. на наявність хронічних захворювань. Вік обстежених був у межах 16-18 років. 3 них сільських жителів було 76 (76 \%), а міських - 24 (24 \%); переважали особи жіночої статі (93\%).
Серед обстежених виявлено 71 (71 \%) здорових студентів, які не мали ніяких хронічних захворювань, та 29 (29 \%) студентів, які мали ті чи інші хронічні захворювання та вади. Отже, практично кожен третій студент мав те чи інше хронічне захворювання.

Щодо поділу здорових студентів за статтю, виявлено, що серед 71 (100 \%) здорових студентів було 65 (91,5 \%) жіночої статі та 6 (8,5 \%) - чоловічої.

При порівнянні питомої частки здорових і хворих студентів окремо серед чоловіків і жінок отримано дані, що серед 93 студентів жіночої статі було 28 хворих $(30,1 \%)$.

Відповідно, серед 7 студентів чоловічої статі був один хворий (14,3\%).

Можна зробити висновок, що питома частка хворих студентів жіночої статі була більшою (30,1 \% проти $14,3 \%)$.

Поділ виявлених хронічних захворювань за групами наведено в таблиці 2.

Таблиця 2. Поділ виявлених хронічних захворювань за групами

\begin{tabular}{|l|c|}
\hline \multicolumn{1}{|c|}{ Група захворювань } & $\begin{array}{c}\text { Кількість } \\
\text { випадків }\end{array}$ \\
\hline Захворювання серцево-судинної системи & 15 \\
\hline Захворювання шлунка та кишечника & 4 \\
\hline Захворювання гепатобіліарної системи & 3 \\
\hline Захворювання сечовидільних шляхів & 2 \\
\hline ЛОР-захворювання & 1 \\
\hline Захворювання щитоподібної залози & 1 \\
\hline Офтальмологічні захворювання & 12 \\
\hline Захворювання опорно-рухового апарату & 5 \\
\hline Всього & 43 \\
\hline
\end{tabular}

Як виявлено, найчастіше мали місце хвороби серцево-судинної системи (15\%) та органа зору (12\%).

При аналізі захворюваності виявлено, що в 14 випадках (48,3 \%) у студентів мало місце 2 поєднаних патології з різних груп (поліморбідність).

Висновки. Результати проведеного дослідження переконливо доводять, що:

1. Серед обстежених виявлено значну питому частку (29 \%) студентів, які мали ті чи інші хронічні захворювання та вади, причому питома частка хворих студентів жіночої статі була більшою (30,1 \% проти 14,3 \%).

2. Найчастіше мали місце хвороби серцево-судинної системи (15 \%) та органа зору (12 \%) і майже у половини випадків спостерігали дві та більше поєднаних патології з різних груп (поліморбідність).

3. У студентів переважно мав місце задовільний результат проби Руф'є (62 \%). Дуже насторожуючим $\epsilon$ 
те, що відмінних результатів не було взагалі, а незадовільних, які свідчать про критичну детренованість серцево-судинної системи, $15 \%$. Практично у 6-7 студентів був критичний стан серцево-судинної системи, що $\epsilon$, без сумніву, вкрай тривожним сигналом та вимагає негайних дій щодо покращення рівня фізичного стану студентів.

4. Ураховуючи достатньо складну і напружену соціально-економічну ситуацію в Україні, зниження економічного добробуту населення, невідповідність умов

\section{СПИСОК ЛІТЕРАТУРИ}

1. Вовченко І. І. Стан здоров'я студентів коледжів / І. І. Вовченко, Н. Ц. Тунік, Т. В. Стаднік // Проблеми фізичного виховання і спорту. - 2010. - № 1. - С. 33-35.

2. Євстратов П. І. Рівень здоров'я в залежності від рухової активності студентів / П. І. Євстратов // Буковинський науковий вісник. - 2005. - С. 209-211.

3. Вовченко І. І. Фізична підготовленість студентів медичного коледжу / І. І. Вовченко, Т. В. Стаднік // Педагогіка, психологія та медико-біологічні проблеми фізичного виховання і спорту : наукова монографія за редакцією проф. С. С. Єрмакова. - Харків : ХДАДМ (ХХПІ), 2008. № 8. - С. 39-41.

4. Волков В. Л. Спрямованість засобів тренувального впливу в процесі фізичної підготовки першокурсників гуманітарних факультетів / В. Л. Волков // Матеріали 10-ї Всеукраїнської конференції аспірантів галузі фізичної культури і спорту. - Львів, 2006. - С. 78. навчального навантаження віковим можливостям студентства, питання охорони і зміцнення здоров'я $\epsilon$ найважливішою складовою освітнього процесу в медичних коледжах. На нашу думку, є необхідність в опрацюванні та запровадженні організаційно-функціональної моделі попередження впливу негативно діючих факторів ризику на стан здоров'я студентівмедиків - як основи управління станом здоров'я майбутніх медичних працівників.

5. Дубогай О. Д. Фактори, які визначають ефективність фізичного виховання студентів спеціальної медичної групи / О. Д. Дубогай // Актуальні проблеми розвитку руху «Спорт для всіх» у контексті європейської інтеграції України : матеріали наук.-практ. конф. - Тернопіль, 2004. - С. 370-374.

6. Вольєва Н. П. Захворюваність студентів вищих навчальних закладів, які належать до спеціальних медичних груп / Н. П. Вольєва, А. С. Вовканич // Спортивна наука України. - 2011. - № 6. - С. 3-11.

7. Москаленко В. Ф. Здоров'я населення і проблеми охорони здоров'я у світі та Європі: стан питання та тенденції (огляд) [текст] / В. Ф. Москаленко // Охорона здоров'я України. - 2003. - № 4. - С. 5-8. 